The Making of Orthodox Byzantium, 600-1025 


\section{NEW STUDIES IN MEDIEVAL HISTORY}

General Editor. Maurice Keen

Roger Collins, Early Medieval Spain:

Unity in Diversity, 400-1000 (Second Edition)

Alan Forey, The Military Orders

from the Twelfth to the Early Fourteenth Centuries

Michael Haren, Medieval Thought:

The Western Intellectual Tradition from Antiquity

to the Thirteenth Century (Second Edition)

Edward James, The Origins of France:

From Clovis to the Capetians, 500-1000

Angus McKay, Spain in the Middle Ages:

From Frontier to Empire, 1000-1500

David Potter, A History of France, 1460-1560

The Emergence of a Nation State

Michael Richter, Medieval Ireland:

The Enduring Tradition

Mark Whittow, The Making of Orthodox Byzantium, 600-1025

Forthcoming:

Jeremy Johns, Early Medieval Sicily:

Continuity and Change from the Vandals to Frederick II, 450-1250 


\title{
The Making of Orthodox Byzantium, 600-1025
}

\author{
MARK WHITTOW
}


(C) Mark Whittow 1996

Maps @ Sue Barnes 1996, under exclusive licence

to Springer Nature Limited 2019

All rights reserved. No reproduction, copy or transmission of this publication may be made without written permission.

No portion of this publication may be reproduced, copied or transmitted save with written permission or in accordance with the provisions of the Copyright, Designs and Patents Act 1988, or under the terms of any licence permitting limited copying issued by the Copyright Licensing Agency, Saffron House, 6-10 Kirby Street, London EC1N 8TS.

Any person who does any unauthorized act in relation to this publication may be liable to criminal prosecution and civil claims for damages.

The authors have asserted their rights to be identified as the authors of this work in accordance with the Copyright, Designs and Patents Act 1988.

First published 1996 by

RED GLOBE PRESS

Red Globe Press in the UK is an imprint of Springer Nature Limited, registered in England, company number 785998, of 4 Crinan Street, London, N1 9XW.

Red Globe Press ${ }^{\circledR}$ is a registered trademark in the United States, the United Kingdom, Europe and other countries.

ISBN 978-0-333-49601-5 ISBN 978-1-349-24765-3 (eBook)

This book is printed on paper suitable for recycling and made from fully managed and sustained forest sources. Logging, pulping and manufacturing processes are expected to conform to the environmental regulations of the country of origin.

A catalogue record for this book is available from the British Library.

A catalog record for this book is available from the Library of Congress. 


\section{Contents}

List of Maps vii

Transliteration and References viii

List of Abbreviations $\quad$ ix

Chronological List xiv

Preface $\quad$ xxv

1. SOURCES FOR EARLY MEDIEVAL BYZANTIUM 1

2. THE STRATEGIC GEOGRAPHY OF THE NEAR EAST 15 The Balkans $\quad 15$

The Steppes $\quad 19$

Anatolia and Iran $\quad 25$

The Agricultural Plains $\quad 30$

The Desert $\quad 32$

Conclusion: a Strategic Geography $\quad 36$

3. THE ROMAN WORLD IN $600 \quad 38$

The Strategic Outlook 38

The Social and Economic Base 53

4. THE FALL OF THE OLD ORDER 69

The Last Roman-Persian War 69

The Islamic Conquests $\quad 82$

The End of the Ancient Economy, c.650-750 89

5. HOW THE ROMAN EMPIRE SURVIVED 96

From Rome to Byzantium $\quad 96$

How the Empire Survived: the City of Constantine and Theodosios $\quad 98$

Taxation $\quad 104$

The Imperial Court $\quad 106$

The Army and Navy 113

$\begin{array}{ll}\text { The Church } & 126\end{array}$

6. THE SHOCK OF DEFEAT 134

The Byzantine World View 134

Icons and Iconoclasm 139

Iconoclasm and the Making of Orthodox Byzantium 159 
7. THE BYZANTINE RESPONSE: ON TO THE DEFENSIVE

Adapting the Late Roman Military Tradition $\quad 165$

Byzantine Defensive Strategy, c.750-c.950 175

The Size of the Byzantine Army 181

8. THE BYZANTINE EMPIRE AND ITS NON-MUSLIM NEIGHBOURS, $c .600-c .950$

Transcaucasia

The Khazars

The Rus

241

The Balkans

262

The Western Provinces

298

9. THE AGE OF RECONQUEST, 863-976 310

The Byzantine Offensive in the East 310

The Decline of the Abbāsid Caliphate 327

The Costs of Success: Byzantium, 863-976 335

10. THE REIGN OF BASIL II, 976-1025 358

The Byzantine World in $976 \quad 358$

The Great Civil Wars, 976-89 361

The Triumph of Constantinople, 990-1025 374

$\begin{array}{ll}\text { Notes } & 391\end{array}$

Bibliography $\quad 424$

Index $\quad 446$ 


\section{List of Maps}

I The Balkans - physical geography 16

II The steppe world, from the Inner Asian frontiers of China to the Hungarian plain 20

III Anatolia, Iran and the Fertile Crescent 26

IV The Roman empire in $600 \quad 39$

V Roman-Persian frontier in the late sixth
and early seventh centuries

VI Anatolia - cities, rivers and relief 92

VII Constantinople in the early Middle Ages $\quad 100$

VIII Imperial territory and the themes, $c .700 \quad 114$

IX Imperial territory and the themes, $c .917 \quad 166$

$\mathrm{X}$ The Transcaucasus 196

XI Eastern Europe in the early tenth century 224

XII Bulgaria and the Balkans 264

XIIIa Italy in the sixth and seventh centuries $\quad 300$ XIIIb Italy in $c .980 \quad 301$

XIV The Eastern Offensive, $c .860-c .1025 \quad 312$ 


\section{Transliteration and References}

Greek names and place names are transliterated with $k$ s and os, save where a Latinate or Anglicised version is so familiar that it would be pedantic to use anything else: therefore Nikephoros, Herakleios, Kaisareia, but Nicaea, Thessalonica, Cappadocia. Ankara appears rather than Ankyra on an analogous principle. Modern place names in Turkey follow current Turkish useage; Arabic names and place names follow a simplified version of that in the Encyclopaedia of Islam, New Edition (Leiden, 1960- ). In particular the Arabic $q \bar{a} f$ is transliterated as $k$ rather than $q$ and $d j \bar{\imath} m$ as $d j$ rather than $j$ or $\check{g}$. Hence Kälikāala rather than Qāliqāla, and Djabala rather than Jabala or Ğabala. The 'ain has generally been omitted, but a diacritical line (-) indicating a long vowel seems useful as a guide to pronunciation.

The endnotes give specific references to texts, and to secondary literature of immediate relevance. Primary and secondary works that underpin a chapter in a more general way are found in the chapter bibliographies at the back of the book, together with a guide to further reading. 


\section{List of Abbreviations}

AASS

$A B$

$A C O$

BAR, Int. Ser.

BASOR

BBTT

BMGS

$B y z$

$B Z$

CFHB

CSHB

Chron. 1234

CSCO

DAI

De Cer.

De Cer., ed. Vogt
Acta Sanctorum (Brussels, 1643- )

Analecta Bollandiana

Acta Conciliorum Oecumenicorum, ed. E.

Schwartz, 5 vols in 32 parts (Berlin and

Leipzig, 1922- )

British Archaeological Reports,

International Series

Bulletin of the American Schools of Oriental

Research

Belfast Byzantine Texts and

Translations

Byzantine and Modern Greek Studies

Byzantion

Byzantinische Zeitschrift

Corpus Fontium Historiae Byzantinae

Corpus Scriptorum Historiae

Byzantinae

Anonymi auctoris chronicon ad annum

Christi 1234 pertinens, 2 vols (CSCO CIX, CCCLIV, Scriptores Syri LVI, CLIV,

Louvain, 1937-74)

Chronikon Paschale Chronicon Paschale, ed. L. Dindorf (Bonn, $1832)$; tr. M. Whitby and M. Whitby, Chronicon Paschale 284-628 AD

(Translated Texts for Historians VII, Liverpool, 1989)

Corpus scriptorum christianorum orientalium

Constantine Porphyrogenitus, De

Administrando Imperio, ed. Gy.

Moravcsik, tr. R. J. H. Jenkins (CFHB I, Washington, D.C., 1967)

Constantinus Porphyrogenitus, De cerimoniis aulae Byzantinae libri duo, ed.

J. J. Reiske (Bonn, 1829-30).

Constantin VII Porphyrogénète, Le

Livre des Cérémonies, 2 vols, ed. A. Vogt

(Paris, 1935-40) 
$\mathbf{x}$

De re militari

$D O P$

$E I / 2$

Genesios

GM cont.

HUS

JGR

$J O ̈ B$

Laurent/Canard

Lemerle, Les plus anciens recueils

Leo Gram.

Liber pontificalis

Liber pontificalis

tr. Davis I

\section{LIST OF ABBREVIATIONS}

Three Byzantine Military Treatises, ed. and tr. G. T. Dennis (CFHB XXV, Washington, D.C., 1985), pp. 246-335

Dumbarton Oaks Papers

The Encyclopaedia of Islam, New Edition (Leiden, 1960- )

Josephus Genesius, Iosephi Genesii regum libri quattuor, ed. A. Lesmueller-Werner and $\mathrm{H}$. Thurn (CFHB xiv, Berlin, 1978)

Georgius Monarchus, Vitae imperatorum recentiorum, in Theophanes

Continuatus, ed. I. Bekker (CSHB, Bonn, 1838), pp. 763-924

Harvard Ukrainian Studies

Jus Graecoromanum, ed. J. Zepos and P.

Zepos, 8 vols (Athens, 1931)

Jahrbuch der Österreichischen Byzantinistik

J. Laurent, L'Armenie entre Byzance et l'Islam depuis la conquête arabe jusqu'en 886, rev. M. Canard (Lisbon, 1980) P. Lemerle, Les plus anciens recueils des miracles de saint Démétrius, 2 vols (Paris, 1979-81)

Leo Grammaticus, Chronographia, ed. I. Bekker (CSHB, Bonn, 1842)

Le Liber pontificalis, ed. L. Duchesne, 2 vols (Paris, 1886-92); 1 vol., additions, corrections and indices, ed. $\mathrm{C}$. Vogel (Paris, 1957)

The Book of the Pontiffs (Liber

Pontificalis), tr. R. Davis (Translated

Texts for Historians v, Liverpool, 1989) 
Liber pontificalis

tr. Davis II

Mansi

MGH

MGH SRLI

Michel le Syrien

Nik.

$O D B$

Oikonomidès, Les listes

$P G$

PLRE, I-III

PO

Praecepta Militaria

Procopius, Wars
The Lives of the Eighth Century

Popes (Liber Pontificalis), tr. R. Davis (Translated Texts for Historians XIII, 1992)

Sacrorum conciliorum nova et amplissima collectio, ed. J. Mansi, 31 vols (Florence and Vienna, 1759-98)

Monumenta Germaniae Historiae Monumenta Germaniae Historiae: Scriptores rerum Langobardicarum et italicorum saec. VI-IX (Hannover, 1878)

J.-B. Chabot, Chronique de Michel le Syrien, 4 vols (Paris, 1899-1924) Nikephoros, Patriarch of Constantinople, Short History, ed. and trans. C. Mango (CFHB, XIII, Washington, D.C., 1990)

Oxford Dictionary of Byzantium, ed. A. Kazhdan et al., 3 vols (Oxford, 1991)

N. Oikonomidès, Les listes de préséance byzantines des ix et $x^{e}$ siècles (Paris, 1972)

Patrologiae cursus completus, Series graeca, ed. J.-P. Migne, 161 vols (Paris, 1857-66)

Prosopography of the Later Roman Empire, 3 vols, ed. A. H. M. Jones and J. Martindale (Cambridge, 1971-92)

Patrologia Orientalis

'Strategika imperatora Nikifora', ed. J. A. Kulakovskij, Mémoires de l'Académie Imperiale des sciences de St.-Petersbourg, 8th series, hist. phil. class, VIII. 9 (1908), pp. 1-58 Procopius, Wars, ed. and tr. H. B. Dewing, 5 vols (Cambridge, Mass., 1914-28) 
xii

Pseudo-Sym.

$P V L$

REArm

$R E B$

Sebeos, tr. Macler

Sebeos, tr. Bedrosian

Skylitzes

Stephen of Taron i

Stephen of Taron ii

al-Tabari

Theo.

\section{LIST OF ABBREVIATIONS}

Symeon Magister, Annales in Theophanes Continuatus, ed. I. Bekker (CSHB, Bonn, 1838), pp. 601-760

Povest' vremennych let, tr. S. H. Cross and O. P. Sherbowitz-Wetzor

(Cambridge, Mass., 1953)

Revue des études arméniennes, New Series

Revue des études byzantines

Sebeos, Histoire de Héraclius, tr. F.

Macler (Paris, 1904)

Sebēos' History, tr. R. Bedrosian

(Sources of the Armenian

Tradition, New York, 1985)

'Skirmishing Warfare' Three Byzantine Military Treatises, ed. and tr. G. T. Dennis (CFHB XXV, Washington, D.C., 1985), pp. 144-39

Ioannes Skylitzes, Synopsis historiarum, ed. H. Thurn (CFHB v, Berlin, 1973)

Étienne Açogh'ig de Daron, Histoire universelle, tr. E. Dulaurier (Paris, 1883)

Étienne Asolik de Tarôn, Histoire universelle tr. F. Macler (Paris, 1917)

The History of al-Tabarin, ed. I. Abbas et al., 38 vols (SUNY Series in Near Eastern Studies, Albany, New York, 1985- ). [References are given to the volume and page of the Arabic text, ed. M. J. De Goeje, 15 vols (Leiden, 1879-1901) which is quoted in the SUNY English translation.] Theophanes, Chronographia, ed. C. de Boor, 2 vols (Leipzig, 1883). [All references are to the text in vol. I.] 
Theo. Cont.

TIB

$T M$

Vasiliev, Byzance et les Arabes

'Vaticanus Gr. 163'

West-Syrian Chronicles

ZRVI
Chronographia, in Theophanes

Continuatus, ed. I. Bekker (CSHB, Bonn, 1838), pp. 3-481 Tabula imperii Byzantini Travaux et Mémoires

A. A. Vasiliev, Byzance et les Arabes I, La dynastie d'Amorium (820-867), French edn, H. Grégoire, M. Canard (Brussels, 1935); II, La dynastie Macédonienne (867-959), part 1: Les relations politiques de Byzance et des Arabes à l'époque de la dynastie Macédonienne (première période 867-959), French edn, M. Canard (Brussels, 1968); part 2: Extraits des sources Arabes, French edn, H. Grégoire, M. Canard (Brussels, 1950)

A. Markopoulos, 'Le témoinage du Vaticanus Gr. 163 pour la période entre 945-963', Symmeikta III (1979), pp. 83-119 (text, pp. 91100)

A. Palmer, The Seventh Century in West-Syrian Chronicles (Translated Texts for Historians XV, Liverpool, 1993)

Zbornik radova Vizantološkog Instituta 


\section{Chronological List}

Note: Given the evidence available, dates for the Islamic conquest of Syria, Iraq and Egypt can only be probable, but the error is not more than a few years.

Date EMPERORS/Patriarchs
(from 595)

527-65 JUSTINIAN I

$541-2$

Appearance of bubonic plague in Mediterranean.

565-78 JUSTIN II

568

Lombard invasion of Italy.

578-82 TIBERIOS I

$580-3$

Break up of Ghassānid confederation.

582-602 MAURICE

591

595-606 Kyriakos

602

Peace with Persia.

Mutiny of army in Balkans; murder of Maurice.

602-10 PHOKAS

603

607-10 Thomas I

610-41 HERAKLEIOS

610-38 Sergios I

614

Jerusalem falls to

Persians.

616

Persian invasion of Egypt.

624

Beginning of Herakleios' Transcaucasian

campaigns; final loss of southern Spain.

626

Avar-Persian siege of Constantinople.

628 Chronikon Paschale stops; 
630

632

634-8

636

638

638-41 Pyrrhos (first patriarchate)

641 CONSTANTINE III and HERAKLONAS

641 HERAKLONAS

641-68 CONSTANS II

641-53 Paul II

642

653-4

654

654-66

656-61

663

667-9 Thomas II

668-85 CONSTANTINE IV

669-75 John $\mathrm{V}$

c. 670

$674-8$

675-7 Constantine I

677-9 Theodore I (first patriarchate) fall of Khusro II.

Herakleios restores

'True Cross' to

Jerusalem.

Traditional date for death of the prophet Muhammad.

Arab conquest of Iraq;

fall of Ctesiphon.

Battle of Yarmūk; Arab conquest of Syria.

Herakleios issues Ekthesis promulgating

Monotheletism.
Arab conquest of Egypt. Arabs reach Bosphoros opposite Constantinople.

First Muslim civil war; establishment of Ummayad caliphate. Constans II's expedition to the west.

Khazars establish domination of Ukrainian and Volga steppes. Arab blockade of Constantinople. 
679-86 George I

$680-1$

683-92

685-95

$686-7$

688-94

691-2

694-706 Kallinikos I

695-8 LEONTIOS

698

698-705 TIBERIOS II

705-11 JUSTINIAN II (SECOND REIGN)

705-6

706-12 Kyros

711-13 PHILIPPIKOS

712-15 John VI

713-15 ANASTASIOS II

716-18

715-17 THEODOSIOS III

715-30 Germanos I

717-41 LEO III

726

727

730-54 Anastasios

730

737

740

741-75 CONSTANTINE V
Council of

Constantinople IV (Sixth

Oecumenical Council).

Second Muslim civil war.

Bulgar qaghan Tervel in Constantinople.

Arab siege of

Constantinople.
Volcanic eruption of Thera.

Arab siege of Nicaea; Italian tax revolt.

Iconoclasm official dogma; Khazars raid as far as Mosul.

Arab invasion of Khazaria; qaghan submits.

Byzantine victory over Arabs at Akroïnos. 
$741-3$

$744-7$

$749-50$

751

753

754-66 Constantine II

$759-75$

766-80 Niketas I

774

775

775-80 LEO IV

780-4 Paul I

780-97 CONSTANTINE VI (IRENE, REGENT 780-90)

782

784-806 Tarasios

787

796

797-802 IRENE

800

802-11 NIKEPHOROS I

c.802-14

806-15 Nikephoros I
Revolt of Artabasdos.

Third Muslim civil war.

Overthrow of Ummayad caliphate; establishment of Abbāsid caliphate.

Lombards conquer

Ravenna.

Pope Stephen crosses

Alps to appeal to Peppin

III, king of the Franks,

for military support;

Iconoclast Council of

Hieria.

Constantine V's Bulgar

campaigns.

Charlemagne conquers

Lombard kingdom in

Italy.

Battle of Bagrevand;

Arabs crush Armenian revolt.
Major Arab invasion of Asia Minor reaches

Bosphoros.

Council of Nicaea II; first restoration of icons. Frankish armies destroy Avar qaghanate.

Charlemagne crowned emperor in Rome.

Krum, Bulgar qaghan. 
xviii

806-7

809-33

811

811 STAURAKIOS

811-13 MICHAEL I

812

813-20 LEO V

813

815-21 Theodotos I Kassiteras 815

816

819-37

820-9 MICHAEL II

c. 826

829-42 THEOPHILOS

c.835-9

837?-43 John VII Grammatikos

838

839
821-37? Antony I Kassymatas

Caliph Hārūn

al-Rashīd leads major raids into Asia Minor.

Abbāsid civil war.

Nikephoros I's Bulgar campaign.

Byzantine recognition of western imperial title.

Theophanes'

Chronographia stops.

Council of

Constantinople;

iconoclasm restored as official dogma.

Peace with Bulgars.

Revolt of Babek in Azerbaidjan.

Arab invasions of Crete and Sicily.

Magyars driven into western Ukrainian steppes.

Sack of Amorion.

Byzantine embassy plus Rus envoys to Louis the Pious at Ingelheim.

842-67 MICHAEL III (THEODORA, REGENT, 842-56) 843-7 Methodios

843

846
Restoration of Orthodoxy. Arabs sack St Peter's, Rome. 
847-58 Ignatios (first patriarchate)

851-5

858-67 Photios (first patriarchate)

860

$861-70$

862

863

864-5

866

867-86 BASIL I

867-77 Ignatios (second patriarchate)

869-83

869-70

871

876

877-86 Photios (second patriarchate)

878

879-80

884

885
Bugha the elder crushes

Armenian revolt.

First Rus attack on

Constantinople.

Turkish assassination of caliph al-Mutawakkil followed by nine-year 'anarchy'.

Ašot I Bagratuni

appointed prince of princes by caliph.

Destruction of raiding army of Melitene; Cyril and Methodios sent to

Moravia.

Conversion of Bulgaria.

Caesar Bardas murdered by Basil.
Zandj revolt in Iraq.

Council of

Constantinople

Emperor Louis II

captures Bari from

Arabs.

Byzantines occupy Bari.

Byzantine capture of

Tephrike; Arab capture of Syracuse.

Council of

Constantinople.

Ašot I crowned king of Armenia by caliph.

Moravian mission expelled and takes refuge in Bulgaria. 
$885-6$

886-912 LEO VI

886-93 Stephen I

891

893-901 Antony II Kauleas

893-927

894-6

901-7 Nicholas I Mystikos (first patriarchate)

902

904

907-12 Euthymios

909

911

912-25 912-13 913 Africa).

Nicholas I Mystikos (second patriarchate) ALEXANDER
Byzantine expeditionary force under Nikephoros Phokas the elder campaigns in Southern Italy.

Creation of theme of Longobardia.

Symeon, emperor of the Romans and Bulgars.

Magyars invade Bulgaria;

Pečenegs drive Magyars on to Hungarian plain.

Fall of Taormina in

Sicily to Arabs.

Arab sack of

Thessalonica.

Fātimid caliphate established in Ifrīkiya (North

Byzantine failure to reconquer Crete.

Murder of Smbat

Bagratuni, king of

Armenia by the emir

Yūsuf.

913-59 CONSTANTINE VII PORPHYROGENITOS

913-14 REGENCY COUNCIL

914-19 ZOE, REGENT

915

Byzantine intervention in Armenia; allied Byzantine and Italian forces destroy Arab base at Garigliano (Southern Italy). 
Battle of Achelous:

Bulgars defeat Byzantine

919 invasion force.

920 $920-44$ ROMANOS I LEKAPENOS

921-2

Ibn Fadlan accompanies Abbāsid embassy to the Volga Bulgars.

923 Shī'ite Karmatī begin

925-7 Stephen II

927 raiding Iraq.

Romanos Lekapenos occupies imperial palace; Leo Phokas' coup fails.

Tome of Union

Peace with Bulgars;

Karmatī siege of Baghdad.

927-31 Tryphon

933-56 Theophylact

934

941

942

944

Capture of Melitene (modern Malatya).

Rus attack

Constantinople.

Hamdānids fail to establish control of Baghdad.

$\begin{array}{ll}944-5 & \begin{array}{l}\text { STEPHEN and CONSTANTINE LEKAPENOS } \\ \text { CONSTANTINE VII PORPHYROGENITOS } \\ \text { al-Dawla occupies } \\ \text { Aleppo. }\end{array} \\ 945-59 & \begin{array}{l}\text { arrives in } \\ \text { (active reign) }\end{array} \\ 946 & \begin{array}{l}\text { Būyid occupation of } \\ \text { Baghdad. } \\ \text { Logothete's chronicle } \\ \text { stops. }\end{array} \\ 948 & \text { Failed expedition to }\end{array}$


reconquer Crete;

Liudprand of Cremona's

first embassy to

Constantinople.

955

Bardas Phokas replaced as domestic of the scholai by his son, Nikephoros Phokas.

\section{6-70 Polyeuktos}

959-63 ROMANOS II PORPHYROGENITOS

960

961

Leo Phokas given

triumph in

Constantinople.

962

Theophanes Continuatus stops.

$962 \quad$ Nikephoros Phokas sacks Aleppo.

963-1025 BASIL II and CONSTANTINE VIII PORPHYROGENITOI

963-9 NIKEPHOROS II PHOKAS

964

Failed attempt to reconquer Sicily.

965 Surrender of Tarsos; sack of the Khazar capital, Atil, by Rus.

967 Death of Sayf al-Dawla; annexation of Taron; Svyatoslav and Rus invade Bulgaria.

$968-9$ Liudprand of Cremona's second embassy to Constantinople.

968-70 Otto I invades southern Italy.

969

Byzantines capture Antioch and establish Aleppo as a tributary state; Fātimid conquest of Egypt. 
970-3 Basil I Skamandrenos

971

972

973-8 Anthony III Stoudites 975

976-1025 BASIL II (active reign) 976-9

978-80 Vacancy

980-92 Nicholas II Chrysoberges

981-2

986

987-9

992-6 Vacancy

995

996-8 Sisinnios II

997

998-1001 Vacancy

1000

1001-19 Sergios II

1001

1009
Svyatoslav surrenders to the emperor at Silistra on the Danube; Bulgaria annexed.

Otto II marries

Theophano.

John Tzimiskes'

campaign in Syria,

Lebanon and Palestine.

Revolt of Bardas Skleros.

Būyid embassy in

Constantinople; Otto II's invasion of Southern Italy defeated by Arabs in Calabria.

Basil defeated in Bulgaria.

Revolt of Bardas Phokas.

Basil relieves Fātimid siege of Aleppo; arrest of Eustathios Maleinos.

Battle of Sperchios (Greece); Nikephoros Ouranos defeats Bulgars.

Byzantine occupation of lands of David of Tao (Western Transcaucasus).

Basil agrees ten-year truce with Fātimids. Caliph al-Hākim orders destruction of church of 
xxiv

1009-18

1014

1018

1019-25 Eustathios

1022

1025-8 CONSTANTINE VIII 1025
CHRONOLOGICAL LIST

Holy Sepulchre in

Jerusalem.

Revolt of Meles in

Southern Italy.

Battle of Kleidon: Basil

defeats Bulgars; death of

Samuel, emperor of the

Bulgars.

Bulgar submission.

Former kingdom of

Vaspurakan (Armenia)

becomes Byzantine

province; Phokas revolt

in Cappadocia;

John-Smbat Bagratuni

pledges to leave the

kingdom of Ani

(Armenia) to the empire on his death; Emperor

Henry II's invasion of

Southern Italy fails.

Expedition to reconquer Sicily, planned before

Basil's death, defeated. 


\section{Preface}

THE NEED for a new introduction and survey of Byzantine history between 600 and 1025 hardly requires to be justified, but two points may strike the reader as unexpected.

Firstly, I have set the Byzantine world in a very broad perspective. The geographical introduction ranges from Iran to Italy, and a large portion of the book deals with the empire's neighbours in the Transcaucasus, the steppes and the Balkans. I have done so partly because I do not believe that events inside the empire can be understood without a basic appreciation of this wider world, and partly because there is very little else published in English that fills this gap.

Secondly, this book is not a 'textbook synthesis', but a personal interpretation that some may regard as controversial. Although I hope that the reader will find here a clear and reliable coverage of events, institutions, and social, economic and cultural change, historical research thrives at all levels when there is something to argue about, and if some of the interpretations in this book are greeted by specialists - and even more by their students - with a chorus of disagreement then it will have served one of its purposes.

Among the chief pleasures of writing a book is thanking people. I owe an enormous debt to James Howard-Johnston and Cyril Mango, for their help, advice and encouragement. Sue Barnes prepared the maps for publication; I am very grateful for her skill and care. My thanks to Hugh Barnes, Robert Beddard, Jeremy Catto, Clive Foss, John France, Simon Franklin, Peter Heather, Stephen Humphreys, Jeremy Johns, Christopher Lightfoot, Michael Maas, Alison McQuitty, Mark Nesbitt, Alan Walmsley and Bryan Ward-Perkins, who have all generously given information, listened as ideas took shape, and saved me from some of my errors. I am also happy to acknowledge the kindness and support I have received from the Provost and Fellows of Oriel College, Oxford, and the early encouragement in things Byzantine given by Michael Maclagan - with whom I shall always associate the pleasures of drinking madeira. The book, however, is dedicated to my wife, Helen, and to her father, Dugald Malcolm, without either of whom it would not have been written. 